Review

\title{
Environmental Factors Causing the Development of Microorganisms on the Surfaces of National Cultural Monuments Made of Mineral Building Materials-Review
}

\author{
Elżbieta Stanaszek-Tomal \\ Chair of Building Materials Engineering, Faculty of Civil Engineering, PK Cracow University of Technology, \\ 24 Warszawska Street, 31-155 Cracow, Poland; estanaszek-tomal@pk.edu.pl
}

Received: 9 October 2020; Accepted: 9 December 2020; Published: 10 December 2020

\begin{abstract}
The ability of microorganisms to degrade building materials depends on several factors. Biological corrosion occurs in close dependence with chemical and physical factors affecting microorganisms. The growth and development of microorganisms is stimulated by external stimuli, i.e., environmental factors. Microorganisms have a relatively large tolerance range for changes in environmental conditions. Under the right conditions, microorganisms thrive very well. The adverse effects may cause the inhibition of cell growth, damage, or lead to the death of the microorganism. Considering the impact of environmental factors on microorganisms, it is not possible to identify the most important of them. The result effect of overlapping factors determines the possibility of the growth of certain microorganisms. The main factors affecting the growth are temperature, humidity, hydrogen ion concentration in the environment, oxidoreductive potential, water activity in the environment, and hydrostatic pressure. This article provides a comprehensive overview of the factors causing biodeterioration. The influence of external/internal environment on the surface of cultural monuments made of mineral building materials, i.e., stone, concrete, mortar, etc., is presented.
\end{abstract}

Keywords: biodeterioration; factors; humidity; temperature; $\mathrm{pH}$; culture heritage; stone

\section{Introduction}

The problem of destruction of building materials by microorganisms, i.e., molds and bacteria, is a challenge for today's material developers [1]. They may be originally contaminated with microorganisms. However, monuments in the form of sculptures, paintings, buildings. and national cultural heritage are also under threat [2]. Not only are indoor materials exposed to microorganisms, but so are outdoor materials. Those that are inside can also be contaminated with microorganisms. It can generally be assumed that all materials are susceptible or bio-sensitive to biodeterioration. So let us find out what factors cause microbial corrosion.

Biodeterioration is defined as undesirable changes in material properties caused by biological agents. With regard to the deterioration of materials, biodeterioration can be classified as biophysical, biochemical and aesthetic [1]. Biophysical or biomechanical deterioration refers to the reduction of physical and mechanical properties of a material. As a consequence, formerly durable materials become brittle and fragile [3].

Biochemical degradation processes include processes of assimilation and dissimilation, and loss of MOE (modulus of elasticity), MOR (modulus of rupture), or mass [4].

The former process occurs when organisms digest the material for food. The latter process occurs when microbial metabolites react with the components of the material. Then, corrosion, an aesthetic change to the material and the release of toxic metabolites occur. 
The ability of microorganisms to degrade building materials depends on several factors. Biodeterioration takes place in close relation to the chemical and physical factors affecting the microorganisms. The growth and development of microorganisms is stimulated by external stimuli, i.e., environmental factors. Microorganisms display a relatively wide range of tolerance to changes in environmental conditions. Under the right conditions, microorganisms develop very well. Under adverse conditions, they can cause the inhibition of cell growth or damage or lead to the death of the microorganism. When considering the effect of environmental factors on microorganisms, it is not possible to identify the most important one. The result of multiple overlapping factors determines the possibility of the growth of specific microorganisms [3]. The main growth factors are temperature, humidity, concentration of hydrogen ions in the environment, oxidoreduction potential, water activity in the environment, and hydrostatic pressure [5]. The factors influencing the biodeterioration may be mutually dependent. They can be divided into groups, as presented in Figure 1.

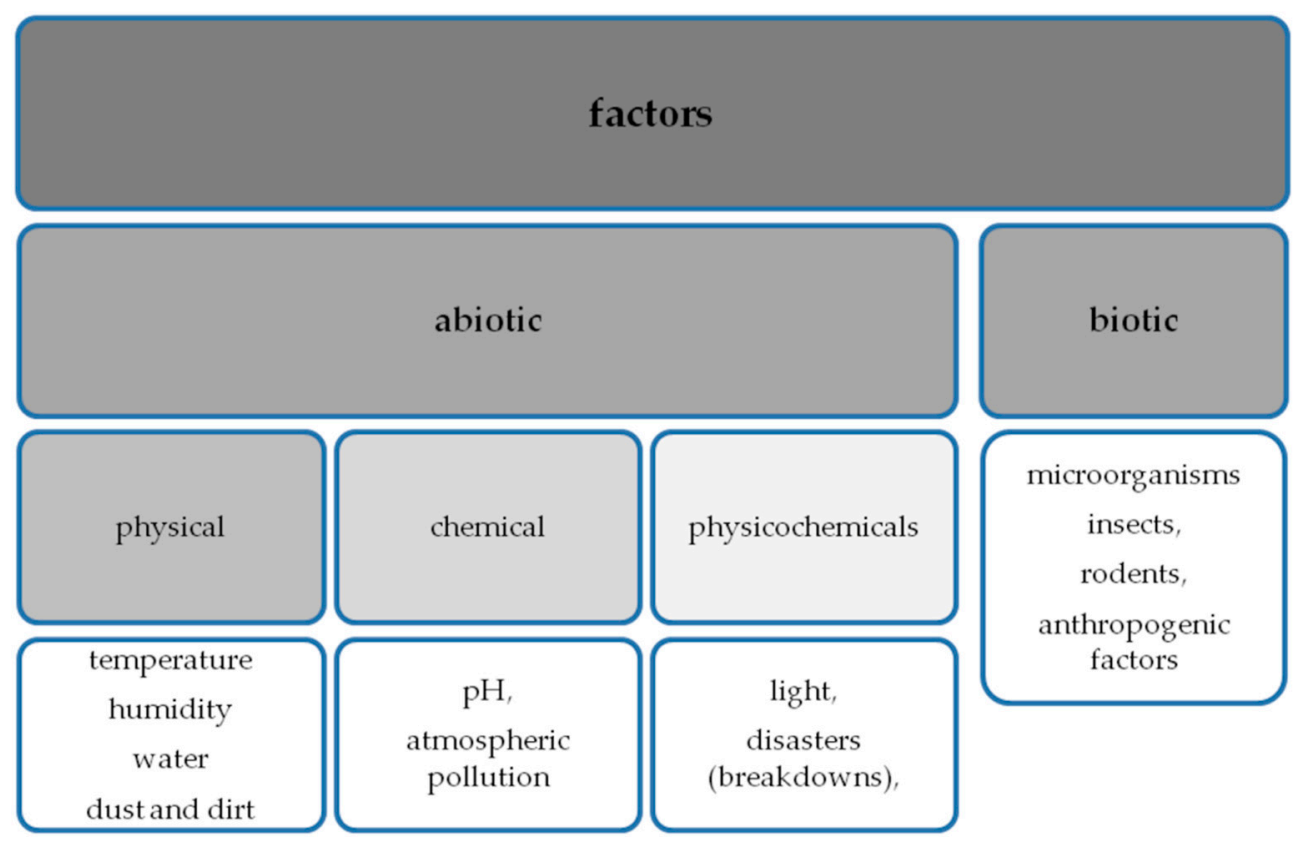

Figure 1. Factors that cause biodeterioration and can coexist and depend on each other [6].

\section{Factors Influencing the Development of Microorganisms}

For material-decomposing microorganisms, air and substrate humidity are quite important factors. The availability of water is determined by the indicator of hygroscopic equilibrium (water activity) $a_{w}$ [7].

$$
\mathrm{a}_{\mathrm{w}}=\mathrm{p} / \mathrm{p}_{0}=\mathrm{N}_{2} /\left(\mathrm{N}_{1}+\mathrm{N}_{2}\right)
$$

This index expresses the ratio of vapor pressure in the material $-\mathrm{p}$ to vapor pressure over water at the same temperature and pressure- $\mathrm{p}_{0} ; \mathrm{N}_{1}$-the number of moles of the substance dissolved; $\mathrm{N}_{2}$-the number of moles of the solvent (water). In practical analyses, the equivalent of relative humidity of gaseous environment, i.e., air $\varphi\left(\mathrm{a}_{\mathrm{w}}=0.6\right.$ is equivalent to $\left.\varphi=60 \%\right)$ is used [7]. All microorganisms grow excellently at the hygroscopic equilibrium index $a_{w}$ close to 1.0. For fungi, the minimum value of $a_{w}$ at which their growth is possible varies significantly. The ambient temperature and food availability are important. There is an inversely proportional relationship between the ambient temperature and the $a_{w}$ value at which fungal growth is possible $[8,9]$. Table 1 shows the minimum water activity value for different microorganisms. 
Table 1. Minimum water activity value for different microorganisms [10].

\begin{tabular}{cc}
\hline Microorganisms & Water Activity \\
\hline G(-) bacteria, some yeasts & 0.95 \\
Sea algae & 0.92 \\
Vegetative cells, certain molds & 0.91 \\
Staphylococci & 0.85 \\
most yeasts & 0.88 \\
most molds & 0.80 \\
halophytic: bacteria, algae & 0.75 \\
osmophilic yeasts, xerophilic molds & 0.60 \\
\hline
\end{tabular}

Fungi will grow at a relative air humidity of $40 \%$ or more [11]. Exceeding this value will irrevocably cause fungi to grow on building and finishing materials. This applies both to flats, houses, and public facilities, as well as livestock housing where both animals and people are present [12].

The causes of dampness in building materials and partitions include:

- precipitation,

- ground water,

- rainwater,

- process and operating water,

- condensation of water vapors on the surface of the partition and inside it,

- damage to installations,

- humid air surrounding partitions and building materials,

- flooding [13].

The development of microorganisms is also associated with phenomena occurring in partition materials and on their surfaces. It concerns the following phenomena: moisture adsorption and absorption, surface tension, water vapor condensation on the surface of partitions, capillary transport of moisture, diffusion and condensation of water vapor inside the partition, and drying of partitions [13].

Temperature as a factor for microbial growth and development shows large fluctuations. Microbial growth is limited by the temperature range presented in Table 2 in which the so-called cardinal temperatures have been presented [10]:

- minimum, below which cell growth and divisions do not occur

- optimal, in which cells grow and divide at the fastest rate

- maximum, above which growth and divisions do not occur

Most organisms develop at ambient temperature in buildings which is usually in the range of $18-20^{\circ} \mathrm{C}$. Fungi have the ability to survive at temperatures much lower or higher than those given. Although they do not have the ability to develop, they can survive by inhibiting their growth $[10,14,15]$.

Table 2. Division of organisms according to growth temperature $[10,15]$.

\begin{tabular}{lccc}
\hline \multicolumn{1}{c}{ Microorganisms } & Min. & Optimal & Max. \\
\hline Psychofiles (grow best at relatively low temperatures) & $>0$ & $10-15$ & $<20$ \\
\hline $\begin{array}{l}\text { Psychotropes (capable of growing at low temperatures, } \\
\text { preferring moderate temperatures) }\end{array}$ & $>0$ & 25 & $15-30$ \\
\hline $\begin{array}{l}\text { Mesophiles (most bacteria mainly coexist with } \\
\text { warm-blooded organisms) }\end{array}$ & $10-15$ & $30-40$ & $<45$ \\
\hline $\begin{array}{l}\text { Thermofiles (including extreme Thermofiles, a group } \\
\text { with high temperature variation) }\end{array}$ & 45 & $50-85$ & $<100$ \\
\hline Hyperthermophiles & 45 & $80-100$ & 110 \\
\hline
\end{tabular}


As with other environmental factors, the optimum $\mathrm{pH}$ value for each microorganism is also distinguished here. Most bacteria prefer an inert or slightly alkaline $\mathrm{pH}$ (approx. 7-7.5) whereas fungi grow better in an acidic environment ( $\mathrm{pH}$ of approx. 5.2-5.6). The products of metabolism of this group of microorganisms contain certain amounts of acids, thus causing a decrease in the $\mathrm{pH}$ value of the substrate [16]. Molds are not very susceptible to changes in the $\mathrm{pH}$ of the environment. They develop best at a $\mathrm{pH}$ of $4-4.5$.

It cannot be definitively stated which range will be optimal for all microorganisms. The classification of microorganisms according to the $\mathrm{pH}$ of the environment in which they occur is shown in Figure 2.

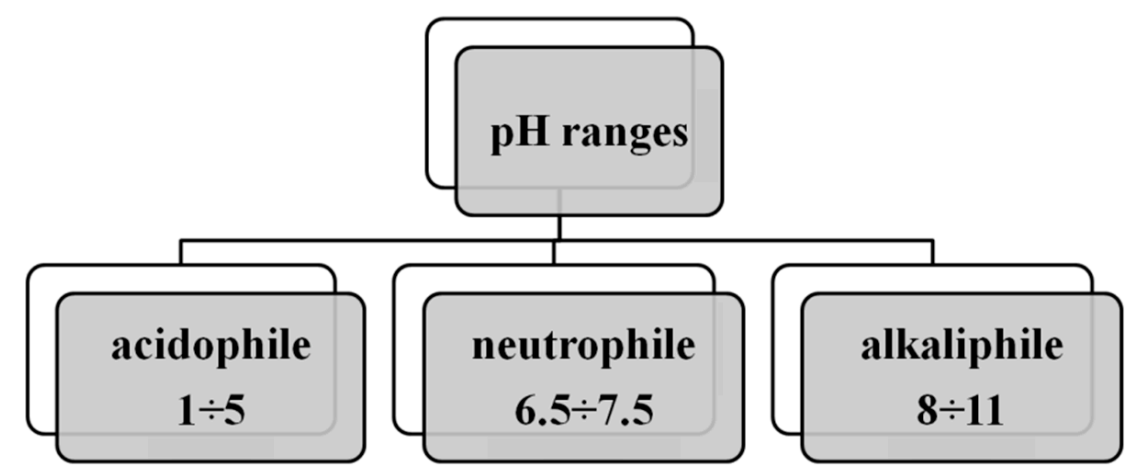

Figure 2. $\mathrm{pH}$ ranges preferred or tolerated by bacteria and fungi [10].

The redox potential is defined as the measurable value of the ability of a biochemical system to accept or donate electrons. The existence of this phenomenon makes the microbial environment more selective. Different $\mathrm{mV}$ values appear. They determine the occurrence of certain species. Depending on the conditions, $\mathrm{mV}$ values range from $+300 \mathrm{mV}$ to even below $-400 \mathrm{mV}$. Only anaerobes develop in an environment with low Eh, while high values favor the growth of aerobic bacteria [17]

There is a clear division of organisms with respect to oxygen requirements:

- absolutely aerobic (absolute aerobes) - require aerobic conditions at atmospheric concentration $(20 \%)$; get their energy through aerobic respiration; the value of the potential is in the range 0.2-0.4. Absolutely anaerobic (absolute anaerobes) - get their energy anaerobically; hydrogen peroxide $\left(\mathrm{H}_{2} \mathrm{O}_{2}\right)$, a strongly oxidizing compound, is formed in metabolic processes in the presence of oxygen; the potential $\left(\mathrm{E}_{\mathrm{h}}\right)$ is below $-0.2 \mathrm{~V}$

- relatively anaerobic - can develop under both aerobic and anaerobic conditions, grow at low atmospheric oxygen concentration, get their energy through aerobic respiration; the value of the potential can be both positive and negative

- microaerophiles-microorganisms that require oxygen to survive but at a low concentration [18].

Atmospheric air is an important factor in the photosynthesis process. Fungal growth is dependent on oxygen availability. In anaerobic conditions or in an environment with large amounts of carbon dioxide, the fungus dies after a few days. The mycelium stops growing when its content in the air exceeds $80 \%$. In favorable aerobic conditions, such as those preceding the lack of carbon dioxide, it can grow again after 15-20 days without oxygen availability $[7,16]$.

Microorganisms can be sensitive to high hydrostatic pressure. Pressure can change microbial metabolism or their inactivation. With respect to their sensitivity to high pressure, microorganisms can be divided into [19]:

- gram-negative bacteria sensitive to high pressure. They can be inactivated at $300 \mathrm{MPa}$ and higher

- fungi that are inactivated at $400 \mathrm{MPa}$ or higher

- gram-positive bacteria resistant to high pressures, inactivated at $600 \mathrm{MPa}$ and higher 
Microbial spore forms (spores) are characterized by very high resistance to high pressures while active forms, i.e., germinating spores, are more sensitive [20]. Some spores can withstand pressures as high as $1200 \mathrm{MPa}$ whereas mild hydrostatic pressure of 25-200 MPa can accelerate their germination.

Osmotic pressure is the force with which water presses against the semi-permeable membrane (plasma membrane) surrounding the cell. Water flows through plasma membrane in response to the uneven distribution of dissolved substances dissolved in the environment. When the microorganism is placed in a hypotonic environment/medium in which the concentration of the dissolved substance outside the cell is lower than inside the cell, water flows into the cell. If this water inflow is uncontrolled, the cell may eventually burst. Most bacteria, algae, and fungi have rigid cell walls that allow them to tolerate and even enjoy a slightly hypotonic environment. Many microorganisms maintain a concentration of the dissolved substance slightly higher in their protoplasm by synthesizing dissolved substances that are compatible with their metabolism and growth, thus keeping the membrane pressed firmly against the cell wall. In contrast, when microorganisms are placed in a hypertonic environment where the concentration of the dissolved substance is higher outside the cell, water is lost from the cell causing dehydration, contraction of the cell membrane and final death [21].

The osmotic concentration of the environment affects the water that is available to the microorganism. With increasing concentration of the dissolved substance in the environment water becomes less easily available. Some prokaryotes can maintain water availability in environments with high dissolved substance concentration (hypertonic environments) by increasing the dissolved substance concentration in the cell. Microorganisms that can do this, and thus tolerate hypertonic environments, are osmotolerant. Osmotolerant bacteria, such as Staphylococcus aureus, can grow in many different environments with different osmotic pressures. In fact, these bacteria can be cultured in media with sodium chloride $(\mathrm{NaCl})$ at concentrations as high as $3 \mathrm{M}$. Some bacteria particularly require environments with high sodium chloride concentrations. These organisms are called halophiles. Osmotic equilibrium (ionic equilibrium) is very important for microorganisms. For some autotrophic bacteria, the presence of organic compounds can be harmful.

A microorganism acquires nutrients from the environment in the form of ions/mineral salts $\left(\mathrm{Na}^{+}, \mathrm{K}^{+}, \mathrm{H}^{+}, \mathrm{NaCl}\right.$, etc.) and inorganic or organic carbon sources $\left(\mathrm{CO}_{2}\right), \mathrm{H}_{2} \mathrm{O}$, gases $\left(\mathrm{O}_{2}, \mathrm{~N}_{2}\right)$, etc. These nutrients are broken down and are present in the cytoplasm (inside the cell). They can be charged, and they also synthesize the required materials, which are also present in the cytoplasm.

In principle, cellular cytoplasm contains many particles of dissolved substance. These charged and uncharged particles exert pressure on cell walls called osmotic pressure, and the cell must maintain this pressure in order to keep the cell wall intact and maintain the shape of the cell, i.e., not to crack or shrink (osmotic equilibrium) [22].

Light has either a stimulating or inhibiting effect on fungal growth. Most fungi need light though it need not be very intense. Diffused light can occasionally leave clear marks on some species, e.g., it inhibits growth and reduces the intensity of dyes. Microorganisms require specific light radiation in order to produce healthy fruiting bodies that are fully capable of reproducing. Fruiting bodies produced without light do not produce spores $[13,23]$. Some fungi exist in the dark. However, they do need light to produce fruiting bodies. Many of them are phototropic. They direct their fruiting bodies towards the sun.

Properly functioning ventilation hinders the absorption of moisture and delays the moment when the surface gets moldy and thus reduces the molded area of the envelope. The mycelium dries faster under stationary conditions when forced circulation does not promote the spread of spores carried by a stream of air. They are released from the surfaces overgrown by mycelium after which they contaminate the air in the room and secondarily infect the surface [24].

In the absence of effective ventilation, the removal of excess moisture from the objects is not possible. As a result of limited ventilation intensity in rooms, the indoor air quality deteriorates significantly. The visible effects of impaired ventilation are [3]:

- dry rot and mold on lintels, jambs, under windowsills, and in corners 
- $\quad$ steamy windows

- condensed water vapor on cool wall surfaces and objects

- $\quad$ air supply through exhaust grilles in the kitchen or bathroom (so-called back draught)

- swelling of wood furniture and floors.

The visible effects of impaired ventilation are deterioration of the building-penetration of moisture into walls and gradual destruction [3].

Proper ventilation of the building is a prerequisite for maintaining a healthy, human-friendly microclimate. Therefore, because the construction industry commonly uses materials with good insulation properties as well as airtight windows and doors, natural ventilation is not sufficient and adequate mechanical ventilation is necessary. The lack of forced ventilation and relying on gravity ventilation only may contribute to the occurrence of harmful dry rot, mold, and bacteria.

An important factor related to microbial infestation is the lack of air movement, which is typical during the heating season. The intensity of their multiplication can be divided into two main groups:

- non-heating season, i.e., the summer period during which climatic conditions indoors are similar to those in outdoor air

- heating season (with intense growth), i.e., the autumn-winter period during which a new microclimate is established.

Fungal spores and bacteria are always present in the air. However, their number depends on the species of the microorganism and the season. Figure 3 shows the concentration of mold spores depending on the season [25]. Approximately $70 \%$ of the air microflora is mold spores, the number of bacteria ranges from $19 \%$ to $26 \%$. The number of yeasts ranges from $4 \%$ to $11 \%$. In summer, the content of mold spores in the air is high.

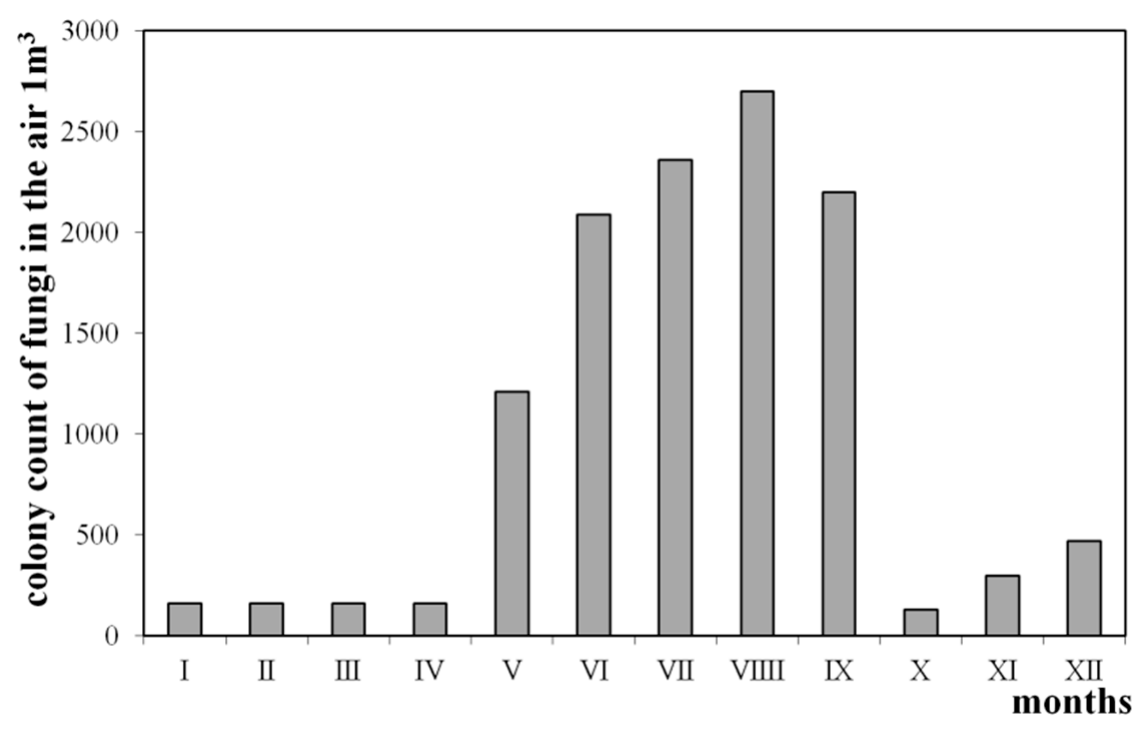

Figure 3. The concentration of mold spores in the room air in the annual cycle [25].

Figure 4 shows microclimatic conditions in dwellings and atmospheric conditions based on microbial contamination susceptibility zones. There is a noticeable shift in the areas that characterize the climatic conditions in the rooms towards the zones at risk of intensive mold growth. In the summer period, there is an intensive growth of microorganisms outside the premises while indoors it is recorded mainly in the autumn and winter period [26]. 


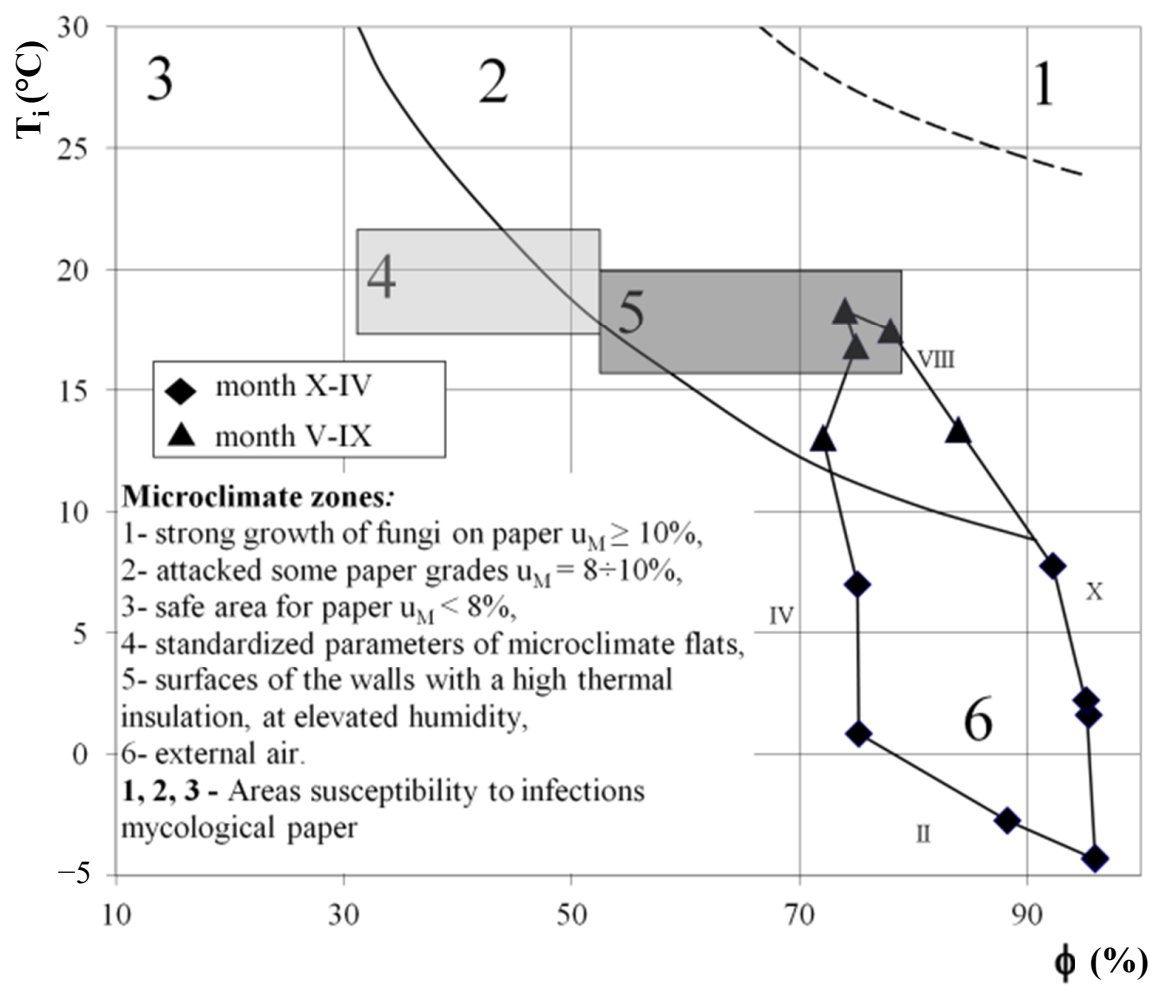

Figure 4. Microclimatic conditions of flats and requirements of molds [25].

In order to grow and reproduce, all bacteria and fungi need a source of energy, carbon, nitrogen, and many other nutrients. Those that constitute the basic building material, i.e., carbon, oxygen, hydrogen, nitrogen, phosphorus, and sulfur, are required in the largest quantities. Apart from the aforementioned components, the presence of iron, magnesium, and the so-called trace elements, which are necessary in very low concentrations (e.g., $\mathrm{Co}, \mathrm{Mn}, \mathrm{Zn}, \mathrm{Cu}, \mathrm{Mo}$, and $\mathrm{Ca}$ ), is necessary in each medium [27].

Particular attention should be paid to the need for energy and carbon source. In the case of autotrophic microorganisms, the energy source is the solar radiation (photoautotrophs) or oxidation energy of reduced inorganic compounds (chemoautotrophs) while the source of carbon is $\mathrm{CO}_{2}$ present in the atmosphere (Table 3) [23,28].

Table 3. Chemo and phototroph's properties [23].

\begin{tabular}{ccc}
\hline Photoautotrophs & Chemotrophs \\
\hline $\begin{array}{c}\text { energy source: solar energy; } \\
\text { carbon source: } \mathrm{CO}_{2} ;\end{array}$ & energy source: as a result of oxidative transformations of inorganic and \\
organic chemicals.
\end{tabular}

For heterotrophies, organic compounds are the source of energy and carbon. In terms of demand for organic compounds, microorganisms are divided into two groups:

- prototrophs, which only require one type of carbon compound to grow, and 
- auxotrophs, which require at least two types of carbon compounds [18].

Another division of heterotrophs distinguishes between saprophytes, which use dead organic substance, and parasites, which develop inside or on another living organism treating it as a specific environment. Parasitism can be symbiotic, antagonistic or asymptomatic [16,18].

There are many species of microorganisms in the air but the most common are Alternaria, Cladosporium, Penicillium, and Aspergillus $[29,30]$. On the other hand, indoor air additionally includes Mucor, Ulocladium, Trichoderma, Chaetomium [31,32] as well as Fusarium, Stachybotrys, and Trichothecium [33] with varied environmental domination. Presented below is a diagram (Figure 5) with the most common fungi isolated from walls and other surfaces in damp buildings. The graph only includes the fungi with the highest rate of occurrence.

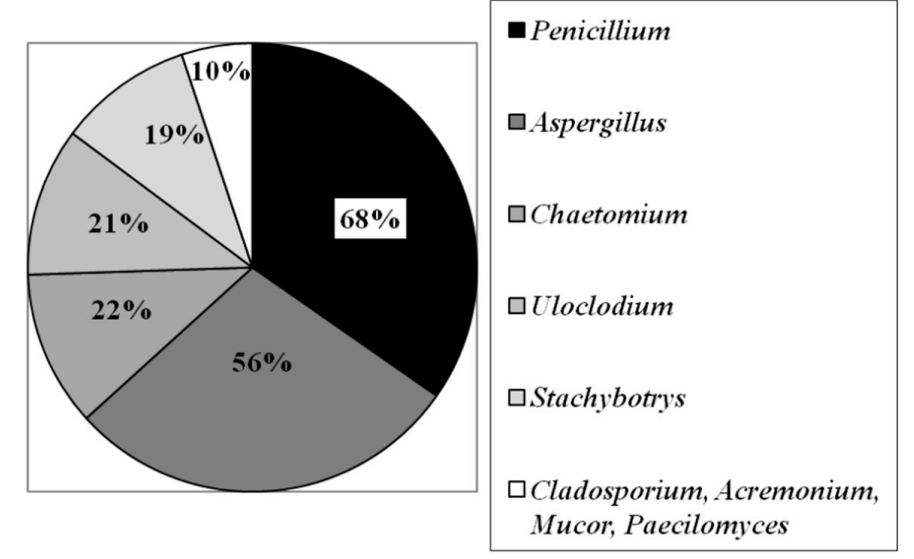

Figure 5. Most frequently insulated molds (with the highest percentage of occurrence) from walls and other surfaces [34].

Mold microflora is introduced into the building through airborne mold spores, occupants' and visitors' clothes, interior design components, animals, plants, etc. These spores are very lightweight, only slightly heavier than the air [35]. They are carried by 'micro-streams' and remain in the inside air for a long time. Their number in the air depends on the way the rooms are used, time of day, season, etc. On their way, as they move and fall, they encounter structural elements of the building. Occasionally, they settle temporarily or permanently on their surface. If optimal conditions for their growth occur, they start to develop.

The literature presents proposals for criteria that can be used as a basis for assessing indoor air quality. Table 4 lists examples of scales used to assess air fungal contamination.

Table 4. Scale for assessing microbiological contamination of air.

\begin{tabular}{|c|c|c|}
\hline Air/Conditions of Occurrence & According to & Permissible Contamination $\left(\mathrm{cfu} / \mathrm{m}^{3}\right)$ \\
\hline Atmospheric & PN-89/Z-04111/03 [36] & $3000 \div 5000$ \\
\hline Bedroom & \multirow{2}{*}{ Krzysztofik et al. [37] } & $\leq 100$ \\
\hline Kitchen & & $\leq 300$ \\
\hline $\begin{array}{l}\text { Very good mycological purity, } \\
\text { there is multi-species microflora }\end{array}$ & \multirow{3}{*}{ Doleżał et al. [38] } & $100 \div 300$ \\
\hline $\begin{array}{c}\text { General Hygiene } \\
\text { anomaly-indication for } \\
\text { further investigation }\end{array}$ & & $>500$ \\
\hline $\begin{array}{l}\text { Very high contamination, active } \\
\text { mold process, predominance of } \\
\text { fungi species }\end{array}$ & & $10^{5} \div 10^{6}$ (up to an uncountable amount) \\
\hline
\end{tabular}


According to a proposal featured in [39], the species Aspergillus fumigatis and Stachybotrys atra are impermissible in the air inside residential facilities. The permissible quantity of molds is $50 \mathrm{cfu}$ (colony forming units) $/ \mathrm{m}^{3}$ if it is one mold species or $150 \mathrm{cfu} / \mathrm{m}^{3}$ if it is a mixture of different species (excluding pathogens). If molds of the genera Cladosporium and Alternaria are predominant in the air, they are acceptable at levels up to $300 \mathrm{cfu} / \mathrm{m}^{3}$. If the limit values are exceeded, testing is necessary to detect the source of infection and how to remove it.

Most building materials are porous bodies whose properties depend both on the chemical composition of the polycrystals and on the percentage, size and distribution of pores.

The colonization of solid surfaces depends on the surface properties of both bodies interacting with each other. These properties include surface charge, surface tension, wettability, composition, porosity, and roughness. Surface charge and surface tension are responsible for interactions over short and long distances (short- and long-range interactions) [40]. Porosity and roughness can promote water absorption and dust adhesion [41,42].

Surface roughness is more important for colonization than the internal surface [43]. Initial colonization begins with surface irregularities, such as cracks or furrows. Moreover, on a rough surface, microorganisms are better protected against shearing forces [44]. Surface roughness may accelerate or slow down the processes of microbial contamination and growth. The higher the roughness of the material, the easier it is for microorganisms to hold and adhere to the surface [45].

The most important condition for microbial growth is increased substrate moisture and its permeability to water.

Hydrophobicity of the surface plays a decisive role in adhesion of microorganisms being even more important than surface charge $[40,46]$. Microorganisms have hydrophilic properties and the higher hydrophobicity of the substrate, the stronger their adhesion to the surface and development of a more stable biofilm. Apart from the above-mentioned properties, surface morphology is also important. Adhesion is increased on porous surfaces due to the larger surface area that binds microorganisms. However, the size of pores is an important feature in surface colonization [47]. The best pore size should be in the range from the smallest cell size of the microorganism to five times the largest cell size of the microorganism. Gaps with dimensions same as microorganisms favour surface colonization [48].

In [46], an increased adhesion of microorganisms was observed in the presence of ions, such as $\mathrm{Ca}^{2+}$ and $\mathrm{Mg}^{2+}$, due to cationic bridges between the negatively charged bacterial surface and the medium.

Microbial growth is also affected by such factors as mineralogical composition or the presence of nutrients $[49,50]$. The chemical composition of the substrate influences growth. It is a potential nutrient supply for microorganisms [51,52]. Materials containing organic compounds are more biosensitive than materials of inorganic composition. When fungi or bacteria act as corrosive agents on technical materials, two mechanisms play an important role. These include biological decomposition and corrosion induced by microorganisms. The type of mechanism depends on the composition of the technical material (Table 5). In general, materials containing organic compounds undergo enzymatic decomposition. Others (with mineral, inorganic composition) undergo corrosion induced by microorganisms and possible surface abrasion.

Table 5. Mineral technical materials that are subject to decomposition or microbiological corrosion [53].

\begin{tabular}{ccc}
\hline Technical Material & Destruction Mechanism & Effects, Destruction \\
\hline $\begin{array}{c}\text { mineral building materials (stone, } \\
\text { concrete, brick, mortar, glass) }\end{array}$ & $\begin{array}{c}\text { corrosion induced } \\
\text { by microorganisms, } \\
\text { surface formation }\end{array}$ & $\begin{array}{c}\text { crushing, cracking, decay, } \\
\text { dissolving, fouling, tarnish, color } \\
\text { changes, pitting, changes in heat } \\
\text { and moisture transfer, weight loss }\end{array}$ \\
\hline
\end{tabular}

One of the important factors affecting the development of microorganisms is the manner of production and storage of building materials [54]. The lack of proper conditions during their production and bad storage cause that they may be the source of emissions of mold spores, mycotoxins and 
volatile compounds [55]. When the contaminated material is built into the building envelope, it will constitute a biological agent. Under favorable conditions, microorganisms will grow and spread to further materials. The fungus will only reveal itself after the whole section of the particular building envelope has been contaminated. The process of fungal infection covers the wall surface, its internal parts and the ceiling, floor, etc., [10].

Microorganisms do not occur as pure cultures of individual cells but accumulate to form "aggregates" called biofilms. In most biofilms, microorganisms make up less than $10 \%$ of dry matter, while the matrix can make up over $90 \%$. The matrix is an extracellular material, produced primarily by the organisms themselves, in which the cells of the biofilm [56]. The biofilm is made up of complex, multi-cellular structures in which numerous microbial cells are surrounded by a layer of mucus [57] and closed in a polymer matrix. In addition to microorganisms (prokaryotic and eukaryotic single-cell organisms), the biofilm consists of conglomerates of various biopolymers, which are often an important part of the biofilm matrix. Biopolymers include DNA, proteins and lipids, which contribute to the matrix and give it various functions. They are called extracellular polymers, or EPS for short. EPS form a scaffold (structure) [58] for the three-dimensional architecture of the biological membrane and is responsible for the surface adhesion and consistency of the biofilm [59]. The biofilm is created in four stages: (a) adhesion of bacteria to the surface, (b) microcolon formation, (c) early development and maturation of the biofilm, and (d) cell dispersion in the surrounding environment, and finally, a return to planktonic state [60]. Exopolysaccharides (EPS) facilitate the adhesion of cells to surfaces. This is a critical stage that then leads to the permanent deposition of the biofilm. The elements that form the biofilm become an integral part of the biofilm's survival. This is linked to the secretion of extracellular enzymes that digest external substrates as a source of nutrients [61].

The creation of biofilms on materials is a common phenomenon. It is present in almost every environment if water is present. Once "anchored" on solid ground, microorganisms form a biofilm. They cause numerous harmful reactions in the surrounding environment. Biofilm is also formed when the microorganisms adhere to surfaces that are permanently under water. Colonization of different surfaces by microorganisms is possible due to their adhesion properties. Adverse changes associated with the formation of biofilm are the cause of serious economic loss [62]. A biofilm composed of both bacteria and fungi may settle on the external surfaces of buildings or monuments, causing their contamination, destruction and lowering their aesthetic value. Biofilm may be formed by individual species of microorganisms, however, most often the hydrogel consists of many types of microorganisms and organic fragments, originating from living cells and corrosion products. These elements constitute a specific, complex ecosystem. In most microorganisms, as a result of colonization, the volume of biofilm increases due to intensive cell division and its thickness (e.g., $30 \mu \mathrm{m}$ or $40 \mu \mathrm{m}$ ) is due to the age of the biofilm and the number of species of microorganisms present. Growing and swelling biofilm becomes a cause of corrosion of materials. Biofilm is an important form and way of survival for microorganisms, protecting them from killing toxins, phagocytes, bacteriocides, and physico-chemical factors.

The biofilm created on the surfaces of materials contains many substances from the environment. These include mineral substances, organic substances, etc., products of interaction with substrates. In this way, the biofilm grows over time. The development of biofilm depends on factors such as temperature, other environmental conditions, substrate type, etc. Biofilm does not grow forever. The decomposition of biofilm can affect many factors. After breaking down the biofilm, microorganisms are released back into the environment. Their "dormant" state is again turned into an active state. They move in search of nutrients and find the surfaces of materials. They stick to them and grow on them. The process is repeated. When renewing this process, there are many types of correlation between the biofilm and the substrate material. Many phenomena in materials are related to the formation and growth of biofilm. For example, corrosion is closely related to the biofilm. This is because a biofilm can trap a certain amount of water on the surfaces of materials and can attach more micro-organisms [63]. 
Stones and other building materials used in architecture, i.e., stones, concrete, and mortars undergo a process of degradation under the influence of microorganisms [64]. Their presence and activity on the above-mentioned heritage materials causes chemical, aesthetic, and physical damage [65]. Microorganisms occur and multiply on cultural heritage for various reasons. The environment in which the monument is located may affect its colonization by microorganisms. Microbiological colonization of stones starts with phototrophic organisms, which form a visible biofilm of enriched organic biomass on the stone surface [66]. The growth and metabolic activity of these algae, cyanobacteria and lichens as well as mosses and higher plants are regulated by such parameters as light and humidity [67]. Bacteria, archaea, and fungi cause serious damage through their enzymatic activity, metabolic processes and corrosion/damage [68]. Chemolitoautotrophic bacteria can release acids, e.g.,:

- nitrous acid, e.g., Nitrosomonas spp.,

- nitric acid, e.g., Nitrobacter spp.,

- $\quad$ sulfuric acid, e.g., Acidothiobacillus spp.

They thus change the local $\mathrm{pH}$ [69], whereas chemo-organotrophic bacteria and fungi can release chelating organic compounds [70] or weaken the structure by oxidizing metal cations such as $\mathrm{Fe}^{2+}$ or $\mathrm{Mn}^{2+}$ [71].

On a building stone, fungi can be the most important bio-deteriorative organisms. Due to their erosiveness [72]. Depending on the physical properties of the material, fungi can penetrate into the stone. In the stone, so-called bi-pitches may be formed (diameter up to $2 \mathrm{~cm}$ and depth). They are mainly caused by black mushrooms. Bio-pitches occur on marble and limestone [73]. These have adapted to different environmental conditions.

\subsection{Inside}

In closed environments, such as museums, churches, etc., the source of microorganisms can be the outside atmosphere and human activity in these places. Microorganisms are present on exposed surfaces of stones, sculptures and walls. They cause a colour change or chemically attack the materials underneath through metabolites [74].

Infections are mainly airborne, and a large number of spores can accumulate in layers of dust. Of course, their amount is subject to seasonal variations [75]. Poor ventilation and heterogeneous surface temperatures create condensation points. This creates a local microclimate with higher water availability than in the rest of the indoor environment. This situation is beneficial for some species of fungi. They can multiply in places where the general environmental conditions seem hostile to microbial life. Temperature and relative humidity, $\mathrm{RH}$, become optimal for the development of micro-organisms, for example in warm environments with a temperature $>20^{\circ} \mathrm{C}$ and humid places with $\mathrm{RH}>65-70 \%$ [76]. In humid conditions of tropical climates, the water/humidity content is high, which is conducive to the successful growth of biofilm and stone plants of monuments and buildings [77].

Black fungi can be found on the rocky surfaces of caves and catacombs [78], especially where naturally high humidity has been actively lowered to inhibit algae growth on valuable wall paintings.

The ability of cyanobacteria to adapt to different qualities of light also allows them to grow on stone in low light-intensity rooms such as crypts, caves and catacombs. There, they are usually the most important factors destroying wall paintings and inscriptions. Eucapsis, Leptolyngbya, Scytonem, and Fischerell [79] were found in these subsurface environments.

The members of the Actinobacteria community settle stone more effectively than most single-celled bacteria. This is due to their filamentous growth and the use of nitrogen and carbon from various sources [78]. Different types of heterotrophic bacteria appear in caves and catacombs [80]. Wall paintings and plaster may contain fungi commonly found indoors, e.g., Cladosporium or Alternaria. This occurs when organic layers-e.g., sucrose, starch, or cellulose-were used to fix the wall painting. Under certain environmental conditions, e.g., uncontrolled humidity and temperature levels, poor ventilation and 
poor conservation, often found in old museums and churches. These environmental conditions are also conducive to the growth of microorganisms in works of art, under prolonged oligotrophic conditions.

In summary, regardless of the type of material used, the microflora consists of a complex ecosystem. It consists of algae, fungi, lichens, bacteria, and protozoa, as well as small animals such as mites and lower and higher plants [72].

\subsection{Outside}

In an outdoor environment with a warm and humid climate, favorable conditions are created for the development of most organisms. Monuments there are degraded and discolored by the action and growth of microorganisms. Then a biofilm is formed on the surface. The aesthetic values are reduced [81]. Microorganisms in moderate climatic conditions grow best on stone surfaces. Phototrophic microorganisms may grow on the stone surface (epithelialphic phototrophs) or may penetrate a few millimeters into the rock pore system (endolytic phototrophs). In tropical and subtropical climatic conditions biodeterioration is accelerated. In these climates, however, microorganisms tend to grow deeper inside the rocks. They protect themselves from the heat of the sun and possible drying out [82]. In this case, the microorganisms become endolites for two reasons. First, they seek nutrients and space. And secondly, they protect themselves against sunlight, temperature fluctuations, wind and drying out, which generally limit the epilite growth [83]. Sometimes they penetrate a few millimeters or even centimeters [84].

Biodegradation processes are characterized by:

- release of corrosive acids-limestone and marble [85];

- alkaline attack on silicate rocks [86];

- uptake and accumulation of sulfur and calcium to cells [87];

- $\quad$ change of stone forming minerals [88];

- and pore widening as a result of penetration of the keel and fiber, loosening stone particles from the parent rock material, mainly on granite rocks [89].

These epilytic and endolytic organisms have the potential to contribute to the decay of crystalline rock structures such as sandstone, granite, gneiss, limestone, dolomite, amphibiolite, basalt, dolerite, bricks and even glazes $[90,91]$

Air pollution in combination with a cold continental climate can also have similar effects. On many, 400-800-year-old specimens from various monuments in Cyprus, microorganisms grew on stone surfaces in winter, at night and formed biofilms even at low temperatures from -10 to $-25^{\circ} \mathrm{C}$ [92].

The mushrooms have adapted to different environmental conditions. In temperate or humid climates, the mushroom communities on the rocks are dominated by hyphomycetes (mold), which form mycelium (nets of shreds) in the porous rock space [93]. Spore deposition from the air is the first step to colonization by fungi. Therefore, the species diversity of stone fungi is quite similar to that of common airborne spores. The most important species include Alternaria, Cladosporium, Epicoccum, Aureobasidium, and Phoma [94]. In dry and semi-arid environments, (in the Mediterranean), climatic conditions are too extreme for most hyphomycetes. Black yeasts and micro-colonial fungi are formed there. Black fungi belong to the genera Hortaea, Sarcinomyces, Coniosporium, Capnobotryella, Exophiala, Knufia, and Trimmatostroma. On and inside the stone they form small black colonies. They often occur in combination with lichens [95]. Due to their thick walls, the fungi are also resistant to chemical attack, i.e., they are resistant to biocides and other antibacterial agents. Black fungi live deep in granite, limestone, and marble, which they destroy by both chemical and mechanical attack. They are the main perpetrators of the bio-pitting phenomenon. Due to the strong melaninization of cell walls, the stones inhabited by these fungi show black spots or can be completely covered with a black layer.

The colonization of external surfaces of buildings by microorganisms causes unsightly discoloration of stone surfaces [96] and the production of extracellular polymer substances (EPS). EPS causes 
mechanical stress in pores of the mineral structure as a result of shrinking and swelling cycles of these colloidal systems [97]. This may lead to changes in pore size and distribution, together with changes in moisture circulation and temperature response patterns [98]. Microorganisms can also change the water permeability of minerals by depositing various factors such as surfactants [99]. The early presence of biofilms on exposed stone surfaces accelerates the accumulation of atmospheric pollutants [100]. Microbiological contaminants act as a precursor to the formation of harmful crusts on the rock surface. They are formed as a result of acidolithic and oxidoreductive erosion of mineral structure [87].

Chemoheterotrophies contribute to the weathering of rocks. This group of micro-organisms has some influence on the consolidation of rocks and gypsum, because they increase the secretion of calcium carbonate in passive and active processes. The strains Bacillus cereus and Myxococcus xanthus have been used for active bioinduction of calcite precipitation to strengthen the monumental stone $[101,102]$.

A frequently observed phenomenon on buildings and wall paintings is the formation of salt efflorescence on wall surfaces [103]. This happens mostly in uncontrolled climate conditions. Salt may be available in the wall itself as a result of biological processes (ammonium salts) or simply as a result of co-circulation with water infiltration. Due to changes in temperature or humidity, salts can precipitate on exposed surfaces. Crystallization of salts on walls and wall paintings causes a destructive effect. Some salts can crystallize to various hydrates. They increase their volume and at the same time take up more space. The result is the creation of additional pressure, leading to cracking and tearing of walls [104]. In addition, salt efflorescences mimic the conditions in extreme habitats that favour the proliferation of halotholerant/halophilic microorganisms such as Gammaproteobacteria and Firmicutes Bacteroidetes and Actinobacteria.

Microbiological contamination changes the physical and chemical properties of the mineral substrate. Microbial biofilms can develop into forms called patina [105]. There are three types of them:

- patina type 1-biofilm formation. It occurs on rocks such as silica sandstone, granite, basalt, slate, limestone, metamorphic rocks (gneiss, quartzite, marble). A single-layer biofilm is formed on the surface or along natural cracks and fissures. The biofilm is dominated by phototrophic microflora or fungi. There are the following biodeterioration processes: discoloration due to the separation of pigments and oxidation of iron and manganese ions; the formation of a biofilm (EPS) and the subsequent development of a thinly flaking coating; local bio-corrosion (bio-pitting) due to the secretion of organic acids by microorganisms.

- Patina type 2-surface corrosion. Occurs on rocks such as volcanic tuff, sintered clays (aluminum binder), silica sandstone, artificial stones (brick, mortar, concrete. Microbial contamination to a depth of $5 \mathrm{~cm}$. Mainly dominated by bacteria. The following biodeterioration processes occur here: biofilm formation) (EPS) narrowing of the pores of the scale, which leads to an increase in capillary rise of water; biocorrosion due to the release of inorganic and organic acids by microorganisms.

- Patina type 3-formation of the crust (deposits). Occurs on rocks with a binder of clay and limestone, material binding. Occurs in the highest layers of stone, it penetrates deeply (max. $1 \mathrm{~cm}$ or with stone slate). Rises complex and stable microflora ("microbial mat"). The following biodeterioration processes exist here: discoloration due to the separation of pigments and oxidation of Fe and Mn ions; the formation of a biofilm (EPS), sealing the pores of rocks due to a reduction in diffusion of moisture and enrichment with atmospheric particles with the subsequent formation of a crust (deposit); biocorrosion due to the release of inorganic and organic acids by microorganisms

\section{Conclusions}

The presence of microorganisms in all natural environments is enormous. Their ability to adapt to environmental conditions and the enormous potential of the metabolites produced have allowed micro-organisms to use almost all technical materials. Temperature and humidity are among the two most important factors. However, the composition of the material, its $\mathrm{pH}$ etc., are equally important for 
the development of microorganisms. The processes of decomposition and microbiological corrosion are related to the metabolism of microorganisms inhabiting certain materials. The mechanism of destruction depends on the type of technical material on which the microorganisms develop. Biofilm is formed on every material and occurs in almost every environment, if water is present.

The environment influences the colonization and development of microorganisms in a particular environment. To summarize [61]:

- In areas with warm, humid climates, they provide favorable environmental conditions for the development of most organisms. Objects undergo degradation and discoloration under the influence of the action and growth of microorganisms. It forms on the surface of the biofilm, thus reducing its aesthetic values.

- In tropical climate conditions, biodegradation and biodeterioration is accelerated.

- In a cold continental climate, air pollution causes similar effects to those mentioned above.

- Microorganisms can also grow on the surfaces of mineral materials in winter, creating biofilms at night at low temperatures from -10 to $-25^{\circ} \mathrm{C}$.

- Inside the rooms, biofilms are produced on the surfaces, colour changes occur and the material/binder is dissolved by the chemical action of the metabolites. Infection of the surface can occur at any temperature and humidity.

To sum up, in outdoor conditions where the environmental parameters are very variable, fungi commonly occurring in the atmosphere appear, i.e., filamentous fungi (when we have a humid and temperate climate).

In a dry or semi-dry environment, black yeast and microcolonial fungi appear less demanding of moisture. There are also connections with lichens.

Virtually any micro-organism can grow in an environment with a warm and humid climate. In an indoor environment, where there is less air circulation, the temperature is more stable and the humidity is regulated or kept constant, fungi occur. Whose spores are found in the inner atmosphere, and cyanobacteria and bacteria. The microorganisms that develop on materials weaken the functional properties of the materials, e.g., tensile strength. They can dissolve the binder. They can cause crushing or delaminating of the emulsion. As a result of microorganisms, materials lose colour or become discolored by dyes produced by microbial cells, e.g., red, yellow, orange, black etc. These microbiological effects are often accompanied by specific odors associated with the production of volatile compounds, such as hydrogen sulfide. Biofilms are a threat to cultural heritage. It is practically impossible to prevent the creation of environments suitable for the development of microorganisms. Therefore, appropriate microbiological risk management methods should be applied.

Heritage sites are valuable to the world, which is why they should be preserved and renovated. For this reason, advanced techniques must be used to identify and control biofilms and physical parameters. Their aim will be to delay the destruction of the sites, allowing future generations to admire this heritage.

Funding: This research received no external funding.

Conflicts of Interest: The author declares no conflict of interest.

\section{References}

1. Bertron, A. Understanding interactions between cementitious materials and microorganisms: A key to sustainable and safe concrete structures in various contexts. Mater. Struct. 2014, 47, 1787-1806. [CrossRef]

2. Gadd, G.M.; Dyer, T.D. Bioprotection of the built environment and cultural Heritage. Microb. Biotechnol. 2017, 10. [CrossRef]

3. Charkowska, A.; Mijakowski, M. Wilgoć, Pleśnie i Grzyby w Budynkach, 1st ed.; Verlag Dashofer: Warszawa, Poland, 2005. 
4. Chen, M.; Wang, C.; Fei, B.; Ma, X.; Zhang, B.; Zhang, S.; Huang, A. Biological Degradation of Chinese Fir with Trametes versicolor (L.) Lloyd. Materials 2017, 10, 834. [CrossRef]

5. Piontek, A.; Lechów, H. Deterioracja Elewacji Zewnętrznych Wywołana Biofilne. Zesz. Nauk. Uniw. Zielonogórskiego 2013, 151, 79-87.

6. Koul, B.; Upadhyay, H. Fungi-Mediated Biodeterioration of Household Materials, Libraries, Cultural Heritage and Its Control. In Fungi and Their Role in Sustainable Development: Current Perspectives; Gehlot, P., Singh, J., Eds.; Springer: Singapore, 2018. [CrossRef]

7. Zyska, B. Mikrobiologiczna Korozja Materiałów, 1st ed.; Wydawnictwa Naukowo-Techniczne: Warszawa, Poland, 1977.

8. Curling, S.F.; Clausen, C.A.; Winandy, J.E. Experimental method to quantify progressive stage of decay of wood by basidomycete fungi. Int. Biodeterior. Biodegrad. 2002, 49, 13-19. [CrossRef]

9. Esener, A.A.; Bol, G.; Kossen, N.W.F.; Roels, J.A. Effect of Water Activity on Microbial Growth; Murray, M.-Y., Robinson, C.W., Vezina, C., Eds.; Scientific and Engineering Principles: Pergamon, Turkey, 1981. [CrossRef]

10. Libudzisz, Z.; Kowal, K. Praca zbiorowa. In Mikrobiologia techniczna, Tom I, 1st ed.; Politechnika Łódzka: Łódź, Poland, 2000.

11. Kostyrko, K.; Okołowicz-Grabowska, B. Pomiary i Regulacja Wilgotności w Pomieszczeniach; Arkady: Warszawa, Poland, 1977.

12. Trechsel, H.R.; Bomberg, M.T. Moisture Control in Buildings-The Key Factor in Mold Prevention Limitation of Access to Water; ASTM International: West Conshohocken, PA, USA, 2009.

13. Ważny, J.; Karyś, J. Ochrona Budynków Przed Korozją Biologiczna; Arkady: Warszawa, Poland, 2001.

14. Czajnik, M. Impregnacja i Odgrzybianie w Budownictwie; Arkady: Warszawa, Poland, 1970.

15. Frisvad, J.C.; Gravesen, S. Penicillium and Aspergillus from Danish homes and working places with indoor air problem: Identification and mycotoxin determination. In Health Implications of Fungi in Indoor Air Environment: Air Quality Monographs; Samson, R.A., Flannigan, B., Flannigan, M.E., Verhoeff, A.P., Eds.; Elsevier: Amsterdam, The Netherlands, 1994.

16. Schlegel, H.G. Mikrobiologia Ogólna, Pod Red. Nauk. Zdzisława Markiewicza; Wydawnictwo Naukowe PWN: Warszawa, Poland, 2003.

17. Brasca, M.; Morandi, S.; Lodi, R.; Tamburini, A. Redox potential to discriminate among species of lactic acid bacteria. J. Appl. Microbiol. 2007, 103, 1516-1524. [CrossRef] [PubMed]

18. Elimer, E. Mikrobiologia Techniczna; Wydawnictwo Akademii Ekonomicznej: Wrocław, Poland, 1999.

19. Malinowska-Pańczyk, E.; Kołodziejska, I. Wpływ wysokiego ciśnienia na mikroorganizmy. Med. Wet. 2005, 61, 150-153.

20. Dudzińska, A.; Domagała, J.; Wszołek, M. Wpływ wysokiego ciśnienia hydrostatycznego na mikroorganizmy występujące w mleku i na właściwości mleka. Żywność Nauka Technol. Jakość 2014, 9, 27-40.

21. Powalowski, S.; Gulewicz, P.; Grajek, W. Wplyw cisnienia osmotycznego na stan fizjologiczny komórek bakteryjnych. Postępy Biol. Komórki 2002, 29, 435-448.

22. Keenleyside, W. Microbiology: Canadian Edition. Open Library PressBooks. Available online: https: //ecampusontario.pressbooks.pub/microbio/front-matter/preface/ (accessed on 20 August 2020).

23. Libudzisz, Z. Mikroorganizmy a Rozkład i Korozja Mikrobiologiczna. I Ogólnokrajowa Konferencja Naukowa "Rozkład i Korozja Mikrobiologiczna Materiałów Technicznych", Poland, 27 Stycznia 2000; Wydawnictwo Politechniki Łódzkiej: Łódź, Poland, 2000.

24. Rymsza, B. Biodeterioracja Pleśniowa Obiektów Budowlanych, 1st ed.; Wydawnictwo Politechniki Poznańskiej: Poznań, Poland, 2003.

25. Mędrela-Kuder, E. Sezonowe Wahania w Występowaniu Grzybów w Powietrzu sal Dydaktycznych oraz w Powietrzu Otwartej Przestrzeni. In Problemy Jakości Powietrza Wewnętrznego w Polsce '99, Poland, 2000; Politechnika Warszawska: Warszawa, Poland, 2000.

26. Jasińska, B. Czynniki środowiskowe determinujące aktywność korozji mikrobiologicznej w budownictwie. In Ogólnokrajowa Konferencja Naukowa "Rozkład i Korozja Mikrobiologiczna Materiatów Technicznych", Poland, 27 Stycznia 2000; Wydawnictwo Politechniki Łódzkiej: Łódź, Poland, 2000.

27. Ważny, J.; Karyś, J. Korozja Biologiczna Betonu, Zapraw i Cegły Wywołana Przez Grzyby Domowe; Kontra: Zakopane, Poland, 2006.

28. Gaylarde, C.; Silva, M.; Warscheid, T. Microbial impact on building materials: An overview. Mater. Struct. 2003, 36, 342-352. [CrossRef] 
29. Domsch, K.H.; Gams, W.; Andersen, T.-H. Compendium of Soil Fungi, 1st ed.; Academic Press: London, UK; New York, NY, USA; Toronto, ON, Canada; Sydney, Australia; San Francisco, CA, USA, 1980.

30. Hyvärinen, A.; Meklin, T.; Vepsäläinen, A. Fungi and actinobacteria in moisture-damaged building materials-Concentrations and diversity. Int. Biodeterior. Biodegrad. 2002, 49, 27-37. [CrossRef]

31. Piontek, M. Pleśnie występujące w obiektach budowlanych w województwie lubuskim. In II Ogólnokrajowa Konferencja Naukowa "Rozkład i Korozja Mikrobiologiczna Materiałów Technicznych", Poland; Wydawnictwo Politechniki Łódzkiej: Łódź, Poland, 2001; pp. 86-94.

32. Reiß, J. Moulds in the domestic environment. Mycosen 1987, 30, 127-133. [CrossRef]

33. Gutarowska, B.; Żakowska, Z. Elaboration and application of mathematical model for estimation of mould contamination of some building materials based on ergosterol content determination. Int. Biodeterior. Biodegrad. 2002, 49, 299-305. [CrossRef]

34. Flennigan, B. Microbial aerosols in building: Origins, health, implications and controls. In II Konferencja Naukowa "Rozkład i Korozja Mikrobiologiczna Materiałów Technicznych"; Politechnika Łódzka: Łódź, Poland, 2001.

35. Żakowska, Z.; Piotrkowska, M.; Gutarowska, B. Grzyby pleśniowe w budynkach-Zagrożenia mikrobiologiczne dla ludzi i zwierząt. In Proceedings of the IV Warsztaty Rzeczoznawcy Mikologiczno-Budowlanego Polskiego Stowarzyszenia Mykologów Budownictwa, Święta Katarzyna, Poland, 23-25 September 2004.

36. PN-89/Z-04111/03. Ochrona Czystości Powietrza. Badania Mikrobiologiczne. Oznaczenia Liczby Grzybów Mikroskopowych w Powietrzu Atmosferycznym (Imisja) Przy Pobieraniu Próbek Metoda Aspiracyjna i Sedymentacyjna; PKN Polski Komitet Normalizacyjny: Warszawa, Poland, 1992.

37. Krzysztofik, B. Mikrobiologia Powietrza; Wydawnictwo Politechniki Warszawskiej: Warszawa, Poland, 1986.

38. Doleżał, M.; Doleżał, M.; Pieniążek, M. Grzyby Pleśniowe w Budownictwie Mieszkalnym; Inwestprojekt: Łódź, Poland, 1990.

39. Singh, J. Building Mycology: Management of Decay and Health in Buildings, 1st ed.; Taylor \& Francis: Abingdon-on-Thames, UK, 1994.

40. Pereira, M.A.; Alves, M.M.; Azeredo, J.; Mota, M.; Oliveira, R. Influence of physico-chemical properties of porous microcarriers on the adhesion of an anaerobic consortium. J. Ind. Microbiol. Biotechnol. 2000, 24, 181-186. [CrossRef]

41. Tran, T.H.; Govin, A.; Guyonnet, R.; Grosseau, P.; Lors, C.; Garcia-Diaz, E.; Damidot, D.; Devès, O.; Ruot, B. Influence of the intrinsic characteristics of mortars on biofouling by Klebsormidium flaccidum. Int. Biodeterior. Biodegrad. 2012, 70, 31-39. [CrossRef]

42. D’Orazio, M.; Cursio, G.; Graziani, L.; Aquilanti, L.; Osimani, A.; Clementi, F.; Yéprémian, C.; Lariccia, V.; Amoroso, S. Effects of water absorption and surface roughness on the bioreceptivity of ETICS compared to clay bricks. Build. Environ. 2014, 77, 20-28. [CrossRef]

43. Petrozzi, S.; Dunn, I.J.; Heinzle, E.; Kut, O.M. Carrier influence in anaerobic biofilm fluidized beds for treating vapor condensate from the sulfite cellulose process. Can. J. Chem. Eng. 1991, 69, 527-553. [CrossRef]

44. Quirynen, M.B.; Bollen, C.M. The influence of surface roughness and surface-free energy on supra and subgingival plaque formation in man. J. Clin. Periodontol. 1995, 22, 1-14. [CrossRef] [PubMed]

45. Barberoussea, H.; Ruota, B.; Yepremian, C.; Boulon, G. An assessment of façade coatings against colonisation by aerial algae and cyanobacteria. Build. Environ. 2007, 42, 2555-2561. [CrossRef]

46. Teixeira, P.; Oliveira, R. Influence of surface characteristics on the adhesion of Alcaligenes denitrificans to polymeric substrates. J. Adhes. Sci. Technol. 1999, 13, 1243-1294. [CrossRef]

47. Pekhtasheva, E.L.; Zaikov, G.E.; Neverov, A.N. Biodamage and Biodegradation of Polymeric Materials—New Frontiers-References; Smithers Rapra Technology: North Freedom, WI, USA, 2012.

48. Shimp, R.J.; Pfaender, F.K. Effect of surface area and flow rate on marine bacterial growth in activated carbon columns. Appl. Environ. Microbiol. 1982, 44, 471-477. [CrossRef] [PubMed]

49. Uchida, E.; Ogawa, Y.; Maeda, N.; Nakagawa, T. Deterioration of stone materials in the Angkor monuments. Eng. Geol. 1999, 55, 101-112. [CrossRef]

50. Adams, R.I.; Bhangar, S.; Dannemiller, K.C.; Eisen, J.A.; Fierer, N.; Gilbert, J.A.; Green, J.L.; Marr, L.C.; Miller, S.L.; Siegel, J.A.; et al. Ten questions concerning the microbiomes of buildings. Build. Environ. 2016, 109, 224-234. [CrossRef]

51. Gutarowska, B. Metabolic activity of moulds as a factor of building materials biodegradation. Pol. J. Microbiol. 2010, 59, 119-124. [CrossRef] [PubMed] 
52. Hoang, C.P.; Kinney, K.A.; Corsi, R.L.; Szaniszlo, P.J. Resistance of green building materials to fungal growth. Int. Biodeterior. Biodegrad. 2010, 64, 104-113. [CrossRef]

53. Gutarowska, B. Niszczenie materiałów technicznych przez drobnoustroje. LAB Lab. Apar. Bad. 2013, 2, 10-14.

54. Gutarowska, B.; Janińska, B. Ocena stopnia porażenia pleśniami materiałów budowlanych w określonych warunkach mikroklimatycznych. In Ogólnokrajowa Konferencja Naukowa "Rozkład i Korozja Mikrobiologiczna Materiałów Technicznych"; Politechnika Łódzka: Łódź, Poland, 2000.

55. Piotrowska, M.; Żakowska, Z.; Bogusławska-Kozłowska, J. Liczba drobnoustrojów jako kryterium stanu zagrzybienia przegród budowlanych. In Proceedings of the VI Sympozjum PSMB “Ochrona obiektów budowlanych przed korozją biologiczną i ogniem", Wrocław-Szklarska Poręba, Poland, 6-8 September 2001; Volume 2001, pp. 101-104.

56. Currie, C.R. A community of ants, fungi, and bacteria: A multilateral approach to studying symbiosis. Annu. Rev. Microbiol. 2001, 55, 357-380. [CrossRef]

57. Monds, R.D.; O'Tool, G.A. The developmental model of microbial biofilms: Ten years of a paradigm up for review. Trends Microbiol. 2009, 17, 73-87. [CrossRef]

58. Flemming, H.C.; Wingender, J. The biofilm matrix. Nature reviews. Microbiology 2010, 8, 623-633.

59. Schlafer, S.; Meyer, R.L. Confocal microscopy imaging of the biofilm matrix. J. Microbiol. Methods 2017, 138, 50-59. [CrossRef]

60. Martino, P.D. What about biofilms on the surface of stone monuments? Open Conf. Proc. J. 2016, 7, 14-28. [CrossRef]

61. Negi, A.; Sarethy, I.P. Microbial Biodeterioration of Cultural Heritage: Events, Colonization, and Analyses. Microb. Ecol. 2019, 78, 1014-1029. [CrossRef] [PubMed]

62. Kanematsu, H.; Barry, D.M. Biofilm and Materials Science; Springer International Publishing: Cham, Switzerland, 2015. [CrossRef]

63. Kanematsu, H.; Barry, D.M. Formation and Control of Biofilm in Various Environments; Springer Nature: Singapore, 2020.

64. Piñar, G.; Sterflinger, K. Microbes and building materials. In Building Materials: Properties, Performance and Applications; Cornejo, D.N., Haro, J.L., Eds.; Nova Science Publishers: New York, NY, USA, 2009; pp. 163-188.

65. Kakakhel, M.A.; Wu, F.; Gu, J.-D.; Feng, H.; Shah, K.; Wang, W. Controlling biodeterioration of cultural heritage objects with biocides: A review. Int. Biodeterior. Biodegrad. 2019, 143, 104721. [CrossRef]

66. Darlington, A. Ecology of Walls; Heinemann: London, UK, 1981.

67. Ortega-Calvo, J.J.; Arino, X.; Hernandez-Marine, M.; Saiz-Jimenez, C. Factors affecting the weathering and colonization of monuments by phototrophic microorganisms. Sci. Total Environ. 1995, 167, 329-341. [CrossRef]

68. Sterflinger, K.; Piñar, G. Microbial deterioration of cultural heritage and works of art-Tilting at windmills? Appl. Microbiol. Biotechnol. 2013, 97, 9637-9646. [CrossRef]

69. Bock, E.; Ahlers, B.; Meyer, C. Biogene Korrosion von Beton und Natursteinen durch Salpetersäure bildende Bakterien. Bauphysik 1989, 4, 141-144.

70. Ascaso, C.; Sancho, L.; Rodriguez-Pascual, C. Weathering action of saxicolous lichens in maritime Antartica. Polar Biol. 1990, 11, 33-39. [CrossRef]

71. Vourinen, A.; Manterc-Alhonen, S.; Uusinoka, R.; Alhonen, P. Bacterial weathering of Rapakivi granite. J. Geomicrobiol. 1981, 2, 317-325. [CrossRef]

72. Scheerer, S.; Ortega-Morales, O.; Gaylarde, C. Microbial deterioration of stone monuments-An updated overview. Adv. Microbiol. 2009, 66, 97-139.

73. Piñar, G.; Garcia-Valles, M.; Gimeno-Torrente, D.; Fernandez-Turiel, J.L.; Ettenauer, J.; Sterflinger, K. Microscopic, chemical, and molecular-biological investigation of the decayed medieval stained window glasses of two Catalonian churches. Int. Biodeterior. Biodegrad. 2013, 84, 388-400. [CrossRef]

74. Abdel-Haliem, M.E.F.; Sakr, A.A.; Ali, M.F.; Ghaly, M.F.; Sohlenkamp, C. Characterization of Streptomyces isolates causing colour changes of mural paintings in ancient Egyptian tombs. Microbiol. Res. 2013, 168, 428-437. [CrossRef] [PubMed]

75. Kaarakainen, P.; Rintala, H.; Vepsalainen, A.; Hyvarinene, A.; Nevalainen, A.; Meklin, T. Microbial content of house dust samples determined with qPCR. Sci. Total Environ. 2009, 407, 4673-4680. [CrossRef] [PubMed]

76. Konkol, N.R.; McNamara, C.J.; Hellman, E.; Mitchell, R. Early detection of fungal biomass on library materials. J. Cult. Herit. 2012, 13, 115-119. [CrossRef] 
77. Liu, X.; Meng, H.; Wang, Y.; Katayama, Y.; Gu, J.D. Water is a critical factor in evaluating and assessing microbial colonization and destruction of Angkor sandstone monuments. Int. Biodeter. Biodegr. 2018, 133, 9-16. [CrossRef]

78. Saarela, M.; Alakomi, H.L.; Suihko, M.L.; Maunuksela, L.; Raaska, L.; Mattila-Sandholm, T. Heterotrophic microorganisms in air and biofilm samples from Roman catacombs, with special emphasis on actinobacteria and fungi. Int. Biodeterior. Biodegrad. 2004, 54, 27-37. [CrossRef]

79. Bellezza, S.; Paradossi, G.; De Philippis, R.; Albertano, P. Leptolyngbya strains from Roman hypogea: Cytochemical and physico-chemical characterisation of exopolysaccharides. J. Appl. Phycol. 2003, 15, 193-200. [CrossRef]

80. De Leo, F.; Iero, A.; Zammit, G.; Urzi, C.E. Chemoorganotrophic bacteria isolated from biodeteriorated surfaces in cave and catacombs. Int. J. Speleol. 2012, 41, 125-136. [CrossRef]

81. Gaylarde, C.C.; Rodriguez, C.H.; Navarro, N.Y.; Ortega, M.B. Microbial biofilms on the sandstone monuments of the Angkor Wat Complex, Cambodia. Curr. Microbiol. 2012, 64, 85-92. [CrossRef]

82. Gadd, G. Geomycology: Biogeochemical transformations of rocks, minerals, metals and radionuclides by fungi, bioweathering and bioremediation. Mycol. Res. 2007, 111, 3-49. [CrossRef] [PubMed]

83. Ragon, M.; Restoux, G.; Moreira, D.; Møller, A.P.; Lopez-Garcia, P. Sunlight-exposed biofilm microbial communities are naturally resistant to Chernobyl ionizing-radiation levels. PLoS ONE 2011, 6, 21764. [CrossRef] [PubMed]

84. Gadd, G. Metals, minerals and microbes: Geomicrobiology and bioremediation. Microbiology 2010, 156, 609-643. [CrossRef] [PubMed]

85. Gehrmann, C.; Krumbein, W.E. Interactions between Epilithic and Endolithic Lichens and Carbonate Rock. In Proceedings of the Third International Symposium on the Conservation of Monuments in the Mediterranean Basin, Venice, Italy, 22-25 June 1994; Volume 1994, pp. 311-316.

86. Gaylarde, C.C.; Morton, L.H.G. Biodeterioration of Mineral Materials; Encyclopedia of Environmental Microbiology Wiley: New York, NY, USA, 2002; pp. 516-527.

87. Ortega-Calvo, J.J.; Arino, X.; Stal, L.J.; Saiz-Jimenez, C. Cyanobacterial sulfate accumulation from black crusts of a historic building. J. Geomicrobiol. 1994, 12, 15-22. [CrossRef]

88. Prieto, B.; Rivas, T.; Silva, B.; Carballa, R.; de Lopez Silanes, E. Colonization by lichens of granite dolmes in Galicia (NW Spain). Int. Biodeterior. Biodegrad. 1994, 34, 47-60. [CrossRef]

89. Romao, P.M.S.; Rattazzi, A. Biodeterioration on megalithic monuments-Study of lichen's colonization on Tapadao and Zambujeiro Dolmens (Southern Portugal). Int. Biodeterior. Biodegrad. 1996, 37, 23-35. [CrossRef]

90. Palmer, R.J.; Hirsch, P., Jr. Photosynthesis-based microbial communities on two churches in Northern Germany: Weathering of granite and glazed brick. Geomicrobiol. J. 1991, 9, 103-118. [CrossRef]

91. Danin, A.; Gerson, R.; Marton, K.; Garty, J. Patterns of limestone and dolomite weathering by lichens and blue-green algae and their palaeoclimatic significance. Palaeogeogr. Palaeoclim. Palaeoecol. 1982, 37, 221-233. [CrossRef]

92. Nuhoglu, Y.; Oguz, E.; Uslu, H.; Ozbek, A.; Ipekoglu, B.; Ocak, I.; Hasenekoglu, I. The accelerating effects of the microorganisms on biodeterioration of stone monuments under air pollution and continental-cold climatic conditions in Erzurum, Turkey. Sci. Total Environ. 2006, 364, 272-283. [CrossRef]

93. Rosling, A.; Finlay, R.D.; Gadd, G.M. Geomycology. In Fungal Applications in Sustainable Environmental Biotechnology; Springer: Cham, Switzerland, 2009; Volume 23, pp. 91-93.

94. Sterflinger, K.; Prillinger, H. Molecular taxonomy and biodiversity of rock fungal communities in an urban environment (Vienna, Austria). Antonie Van Leeuwenhoek 2001, 80, 275-286. [CrossRef]

95. Sterflinger, K. Black yeasts and meristematic fungi: Ecology, diversity and identification. In Yeast Handbook: Biodiversity and Ecophysiology of Yeasts; Rosa, C., Gabor, P., Eds.; Springer: New York, NY, USA, 2005; Volume 1, pp. 505-518.

96. Urzi, C.E.; Krumbein, W.E.; Warscheid, T. On the question of biogenic colour changes of mediterranean monuments (coating-crust-microstromatolite-patina-scialbatura-skin-rock varnish). In Proceedings of the Second International Symptom Conservation of Monuments in Mediterranean Basins, Geneva, Switzerland, 19-21 November 1992; pp. 397-420.

97. Warscheid, T. Impacts of microbial biofilms in the deterioration of inorganic building materials and their relevance for the conservation practice. Int. Z. Bauinstandsetz. 1996, 2, 493-504. 
98. Warscheid, T.; Krumbein, W.E. Biodeterioration of inorganic nonmetallic materials-General aspects and selected cases. In Microbially Induced Corrosion of Materials; Heitz, H., Sand, W., Flemming, H.C., Eds.; Springer: Berlin, Germany, 1996; pp. 273-295.

99. Gaylarde, C.C.; Morton, L.H.G. Deteriogenic biofilms on buildings and their control: A review. Biofouling 1999, 14, 59-74. [CrossRef]

100. Steiger, M.; Wolf, F.; Dannecker, W. Deposition and Enrichment of Atmospheric Pollutants on Building Stones as Determined by Field Exposure Experiments; Conservation of Stone and Other Materials; Thiel, M.-J., Ed.; E \& FN Spon: London, UK, 1993; Volume 1, pp. 35-42.

101. Piñar, G.; Jimenez-Lopez, C.; Sterflinger, K.; Ettenauer, J.; Jroundi, F.; Fernandez-Vivas, A.; Gonzalez-Munoz, M.T. Bacterial community dynamics during the application of a Myxococcus xanthus-inoculated culture medium used for consolidation of ornamental limestone. Microb. Ecol. 2010, 60, 15-28. [CrossRef] [PubMed]

102. Jimenez-Lopez, C.; Rodriguez-Navarro, C.; Piñar, G.; Carrillo-Rosua, F.J.; Rodriguez-Gallego, M.; Gonzalez-Muñoz, M.T. Consolidation of degraded ornamental porous limestone stone by calcium carbonate precipitation induced by the microbiota inhabiting the stone. Chemosphere 2007, 68, 1929-1936. [CrossRef]

103. Amoroso, G.G.; Fassina, V. Stone Decay and Conservation; Elsevier: Amsterdam, The Netherlands, 1983.

104. Saiz-Jimenez, C.; Laiz, L. Occurrence of halotolerant/halophilc bacterial communities in deteriorated monuments. Int. Biodeterior. Biodegrad. 2000, 46, 319-326. [CrossRef]

105. Warscheid, T.; Braams, J. Biodeterioration of stone: A review. Int. Biodeterior. Biodegrad. 2000, 46, 343-368. [CrossRef]

Publisher's Note: MDPI stays neutral with regard to jurisdictional claims in published maps and institutional affiliations.

(C) 2020 by the author. Licensee MDPI, Basel, Switzerland. This article is an open access article distributed under the terms and conditions of the Creative Commons Attribution (CC BY) license (http://creativecommons.org/licenses/by/4.0/). 